\title{
PROFESIONALISME HAKIM DALAM PENYELESAIAN PERKARA PERDATA ISLAM DI PENGADILAN AGAMA PROVINSI BANTEN
}

\author{
Karmawan \\ Universitas Islam Negeri Syarif Hidayatullah Jakarta \\ karmawan@unis. ac.id
}

\begin{abstract}
Abstrak
Penelitian ini bertujuan untuk menganalisis profesionalisme hakim di pengadilan agama di provinsi Banten. Kemudian penelitian ini juga mengkaji putusan-putusan hakim yang sesuai undang-undang dasar 1945 berdasarkan Pancasila untuk mewujudkan tata kehidupan bangsa yang sejahtera, aman, tentram dan tertib dalam kehidupan masyarakat. Untuk mewujudkan tata kehidupan yang demikian dan menjamin persamaan kedudukan warga negara dalam hukum, maka diperlukan upaya untuk menegakkan keadilan, kebenaran, dan kepastian hukum yang mampu mengayoman masyarakat. Dalam rangka menegakkan hukum dan keadilan perkara perdata Islam di Pengadilan agama provinsi Banten diperlukan profesionalime hakim sebagai syarat hakim dalam melaksanakan putusan sesuai dengan nilai-nilai kebenaran dan tanggung jawab sebagai pengadil yang adil. Hakim yang professional dapat memberikan pengayoman bagi masyarakat banyak bergantung pada profesionalisme hakim. Untuk itu syari'at Islam telah menempatkan kedudukan hakim sebagai jabatan yang sangat mulia, kepadanya diberikan kebebasan untuk berijtihad dalam menegakkan hukum dan keadilan.
\end{abstract}

Keywords: Profesionalisme, Hakim, Perdata Islam

\begin{abstract}
This study aims to analyze the professionalism of judges in religious courts in Banten province. Then this study also examines judges' decisions in accordance with the 1945 constitution based on Pancasila to realize a prosperous, safe, peaceful and orderly life order in the life of the people. In order to realize such a way of life and guarantee equality of citizens' position in the law, efforts are needed to uphold justice, truth, and legal certainty that are able to protect the community. In the context of upholding the law and justice of Islamic civil cases in the Banten provincial court, professionalism of judges is needed as a condition for judges to implement decisions in accordance with the values of truth and responsibility as fair judges. Professional judges can provide guidance for many people depending on the professionalism of the judge. For this reason, Islamic Shari'ah has placed the position of judge as a very noble position, to which he is given the freedom to do jihad in enforcing law and justice.
\end{abstract}

Keywords: Professionalism, Judge, Islamic Civil 


\section{Pendahuluan}

Hakim adalah seorang yang harus menilai, menimbang bahwa siapa yang benar, bukti mana yang benar dan digambarkan dalam lembaga peradilan. Hakim mempunyai peran yang sangat strategis dalam persidangan terutama dalam pengambilan putusan. Tugas Hakim adalah memutuskan perkara dengan seadil-adilnya, sementara disisi lain banyak pihak-pihak yang yang merasa benar dan ingin dibenarkan baik itu Penggugat maupun Tergugat, baik itu Pemohon maupun Termohon, apalagi dimungkinkan mereka senantiasa menggunakan kuasanya dengan memanggil pengacara atau orangorang yang dimungkinkan dijadikan sekutu-sekutunya, dalam contohnya saksi bahkan bukti-bukti dan sebagainya yang nantinya akan diajukan di persidangan.

Terbentuk pola etika yang baik dari seorang hakim sangat dipengaruhi dari normanorma yang secara rinci terbagi atas norma hukum, norma moral, norma agama dan norma sopan santun, norma hukum berasal dari undang-undang dimana hakim dalam bertingkah laku dan berfikir berpedoman pada undang-undang yang dalam ini ialah kode etik seorang hakim. Suatu hal yang harus dimiliki seorang hakim dalam memutus perkara haruslah independen, tidak memihak, jujur dan memperlakukan sama semua orang dihadapan

hukum jika hal-hal tersebut terdapat pada diri seorang hakim dapat dipastikan ia merupakan hakim yang baik atau lebih tepatnya berintegritas. Sedangkan profesionalisme hakim dalam menangani perkara haruslah fokus tidak terikat dengan hal-hal lain yang dapat mempengaruhi pribadi seorang hakim dalam pengambilan putusan baik karena pengaruh keluarga, maupun kedudukan para pihak yang ditangani perkaranya. Pertanggungjawaban seorang hakim terkait putusan yang dikeluarkannya tidak hanya kepada para pihak namun pada masyarakat yang secara luas menjadi objek putusannya terlebih kepada Allah Swt yang menuntut pertanggungjawaban diri setiap hambaNya.

Pengambilan keputusan sangat diperlukan oleh hakim atas sengketa yang diperiksa dan diadilinya. Hakim harus dapat mengolah dan memproses data-data yang diperoleh selama proses persidangan, baik dari bukti surat, saksi, persangkaan, pengakuan maupun sumpah yang terungkap dalam persidangan (Lihat Pasal 164 HIR). Sehingga keputusan yang akan dijatuhkan dapat didasari oleh rasa tanggung jawab, keadilan, kebijaksanaan, profesionalisme dan bersifat obyektif. Pada Pasal 5 Undang-Undang No. 48 Tahun 2009 Tentang Kekuasaan Kehakiman, dalam memutus perkara yang terpenting adalah kesimpulan hukum atas fakta yang terungkap dipersidangan. Untuk itu hakim harus menggali nilai-nilai, mengikuti, dan memahami nilai-nilai hukum dan rasa keadilan yang hidup dalam masyarakat.

Hakim adalah pejabat peradilan negara yang diberi wewenang oleh undang-undang untuk mengadili. Dalam Undang-undang Kekuasaan Kehakiman disebutkan bahwa hakim adalah penegak hukum dan keadilan yang wajib menggali, mengikuti dan memahami nilainilai hukum yang hidup di 
masyarakat. ${ }^{1}$ Karenanya, hakim merupakan profesi yang mulia. Seorang hakim dituntut untuk menjalankan kode etika sebagai simbol profesionalisme. Namun dalam perkembangannya, menjadi sebuah keniscayaan akan terjadi gejala-gejala penyalahgunaan terhadap profesi hakim, yang seharusnya dengan penguasaan dan penerapan disiplin ilmu hukum dapat menyelenggarakan dan menegakkan keadilan di masyarakat.

\section{Tinjauan Pustaka}

Dalam konteks pembahasan ini, penulis perlu mengetengahkan beberapa pembahasan yang pernah dilakukan oleh berbagai komunitas akademik dari kajian ini. Nur Fadhil Lubis melakukan penelitian dengan judul "Islamic Justice in Transition: A Socio-Legal of The Agama Court Judges in Indonesia. " Ia mengkaji tentang transisi hakim partikelir menjadi hakim negara. Ia menjelaskan bagaimana pengaruh sosial politik di Indonesia terhadap perkembangan fungsi dan kedudukan hakim agama. ${ }^{2}$ Disini Lubis menjelaskan peran hakim secara formal sebagai hakim negara. Posisi hakim sebagai hakim negara dalam konteks mediasi memiliki peran yang sangat stratregis terutama terkait netralitas penanganan masalah para pihak yang berperkara. Namun demikian, dalam penelitiannya itu Lubis tidak mengarahkan pembahasan ke arah sana.

Penelitian mengenai putusan Pengadilan dilakukan oleh Ritonga. Ia mengkaji putusan-putusan Pengadilan Agama dan relevansinya dengan hak-hak perempuan di Pengadilan Agama Wilayah DKI Jakarta, dengan judul "Hak-hak Wanita dalam Hukum Keluarga Islam di Indonesia: Implementasinya dalam Putusan-putusan Peradilan Agama DKI Jakarta Tahun 1990-1995." Hasil temuannya menegaskan bahwa belum semua putusan Pengadilan Agama responsif terhadap isu gender. Di samping itu, terdapat inkonsistensi putusan dalam kasus perceraian. Perceraian yang diajukan perempuan lebih responsif terhadap isu gender, sebaliknya dalam kasus perceraian yang diajukan oleh suami sangat mengabaikan isu gender. ${ }^{3}$ Ritonga tidak membahas mengenai mediasi, penelitian ini lebih cenderung membahas putusan pengadilan, khususnya putusan responsif jender.

Mu'allim meneliti tentang peran peradilan dalam penyerapan yurisprudensi sebagai sumber hukum dengan judul "Yurisprudensi Peradilan Agama: Studi Pemikiran Hukum Islam di Lingkungan Pengadilan Agama se-Jawa Tengah dan Pengadilan Tinggi Agama Semarang Tahun 1991-1997.” Temuan penelitiannya menegaskan bahwa hakim Pengadilan Agama se-Jawa Tengah sangat mandiri dalam memutus perkara, tidak tergantung dengan yurisprudensi sebagai sumber hukum. Hakim Pengadilan Agama se-wilayah Jawa Tengah dalam memutus perkara lebih mensinergikan berbagai sumber hukum yang dijadikan dasar hukum baik Al-Qur'an, Hadis, kitab fikih, peraturan perundangundangan dan yuriprudensi, bahkan dalam kasus kewarisan sangat jarang menggunakan yurisprudensi

\footnotetext{
${ }^{1}$ Undang-Undang Nomor 4 Tahun 2004 Tentang Kekuasaan Kehakiman Pasal 28 Ayat 1, n.d.

${ }^{2}$ Nur Ahmad Fadhil Lubis, "No Title'Islamic Justice in Transition: A Socio-Legal Study of Agama Court Judges in Indonesia'," 1994.

3 Ritonga, "No Title'Hak-Hak Wanita Dalam Hukum Keluarga Islam Di Indonesia Implementasinya Dalam Putusan-Putusan Peradilan Agama DKI JakartaTahun 1990-1995,,” 2003.
} 
sebagai sumber hukum. ${ }^{4}$ Pola seperti ini lebih mudah melahirkan produk putusan hasil mediasi yang pada umumnya tidak memiliki dasar tekstual dalam sumber hukum Islam.

Manan meneliti putusan-putusan Pengadilan Agama di Wilayah DKI Jakarta dengan fokus masalah pembaharuan hukum Islam yang dilakukan oleh para hakim agama se-DKI Jakarta, dengan judul "Peranan Peradilan Agama dalam Perspektif Pembaharuan Hukum Islam: Studi Kasus Terhadap putusan-putusan di Lingkungan Peradilan Agama DKI Jakarta." Temuan dalam disertasi tersebut menegaskan bahwa hakim agama di wilayah Pengadilan Tinggi Agama Jakarta memiliki peran dalam pembaharuan hukum melalui putusan, dengan menggunakan jenis ijtihad maslahah..$^{5}$ Ijtihad maslahah ini biasa digunakan sebagai dasar hukum hasil mediasi. Namun demikian, produk putusan hasil mediasi tidak dibahas dalam penelitian ini.

Satria Efendi dalam beberapa jurnal Mimbar Hukum Direktorat Jenderal Pembinaan Lembaga Agama Islam Departemen Agama Republik Indonesia melakukan analisa terhadap beberapa putusan Mahkamah Agung Republik Indonesia mengenai hukum perkawinan dan kewarisan yang bersifat parsial sehingga belum memberikan gambaran dinamika pemikiran hukum Mahkamah Agung secara umum. ${ }^{6}$ Demikian pula halnya Jaenal Arifin melakukan penelitian reformasi hukum terhadap Peradilan Agama dengan judul "Reformasi Hukum di Indonesia dan Implikasinya Terhadap Peradilan Agama: Analisis Terhadap Eksistensi Peradilan Agama di Era Reformasi (1998-2008).” Menjelaskan bahwa rekayasa politik dan juga reformasi struktur hukum yang terjadi setelah tahun 1998, tidak memberikan pengaruh serius terhadap Peradilan Agama. Meskipun ada rekayasa politik dari pihak struktural, akan tetapi faktor kultur masyarakat muslim ternyata lebih kuat pengaruhnya bagi keberadaan Peradilan Agama. ${ }^{7}$ Kedua hasil penelitian tersebut tidak secara rinci membahas masalah mediasi. Putusan Mahkamah Agung dimaksud tidak memberikan gambaran adanya hasil mediasi di dalamnya. Sementara reformasi hukum sebagaimana dijelaskan Jaenal Arifin, baru menyentuh aspek kelembagaan, belum menyentuh substansi putusan.

Ahmad ahli menjelaskan bahwa pengalaman dalam suatu pekerjaan atau jabatan tertentu, maka harus mempunyai kriteria umum atau persyaratan yang harus ada pada diri seseorang. Orang yang berpengalaman dalam tugasnya mempunyai keterampilan tinggi dalam suatu bidang pekerjaan, mahir dalam mempergunakan peralatan tertentu yang diperlukan dalam melaksanakan tugas yang dibebankan kepadanya. ${ }^{8}$ Kemudian Sahrwardi K. Lubis, menjelaskan bahwa seorang hakim harus memiliki ilmu pengetahuan yang cukup memadai, pengalaman yang memadai dan mempunyai

4 Amir bin Mu'allim, "No Title'Yurisprudensi Peradilan Agama: Studi Pemikiran Hukum Islam Dilingkungan Pengadilan Agama Se-Jawa Tengah Dan Pengadilan Tinggi Agama Semarang, 1991-1997', Disertasi," 2003.

5 Abdul manan, "'Peranan Peradilan Agama Dalam Perspektif Pembaharuan Hukum Islam: Studi Kasus Terhadap Putusan-Putusan Di Lingkungan Peradilan Agama DKI Jakarta', Disertasi,” 2004.

${ }^{6}$ Satria Effendi, Hukum Keluarga Modern., n.d.

${ }^{7}$ Jaenal Arifin, "“Reformasi Hukum Di Indonesia Dan Implikasinya Terhadap Peradilan Agama: Analisis Terhadap Eksistensi Peradilan Agama Di Era Reformasi 1998-2008)’, Disertasi,” 2008.

${ }^{8}$ Achmad Ali, Menguak Tabir Hukum: Suatu Kajian Filosofis Dan Sosiologis, 2014. 
kecerdasan dalam menganalisis suatu masalah, peka dalam membaca situasi, cepat dan cermat dalam mengambil keputusan yang terbaik untuk kepentingan organisasi. ${ }^{9}$

\section{Metode Penelitian}

Penelitian ini merupakan penelitian yuridis sosiologis yang bersifat kualitatif. Penelitian kualitatif dipergunakan, karena dalam penelitian ini diarahkan pada latar belakang individu secara holistic (utuh). ${ }^{10}$ Penelitian ini bertujuan untuk mengambarkan secara tepat sifat suatu individu, keadaan, atau untuk menentukan frekuensi suatu gejala yang berkaitan dengan penyelesaian sengketa melalui mediasi di pengadilan Agama. Dengan kata lain, pendekatan kualitatif merupakan tata cara penelitian yang menghasilkan data deskriptif yang bertujuan menggambarkan secara tepat sifat suatu individu, keadaan, gejala tertentu, atau untuk menentukan frekuensi suatu gejala, yaitu apa yang dinyatakan oleh sasaran penelitian mengenai penyelesaian sengketa alternatif melalui mediasi di Pengadilan Agama baik tertulis atau lisan, dan perilaku nyata, serta yang diteliti dan dipelajari adalah obyek penelitian yang utuh. ${ }^{11}$

Penelitian ini adalah penelitian sosial yang berlokasi pada kantor Pengadilan Agama se-Provinsi Banten. Penelitian ini menggunakan metode sosio-legal research, yang mana hanya menempatkan hukum sebagai gejala sosial. Itu sebabnya penelitian ini bersifat sosial yang terkait dengan hukum. ${ }^{12}$ Melalui pendekatan tersebut, kajian ini mencoba mencari temuan-temuan berupa fakta sosial untuk membuat keputusan hukum (legal judgement) yang lebih realistis, dan tidak hanya diterapkan dalam proses-proses penciptaan hukum (in abstacto) akan tetapi juga diterapkan dalam proses-proses penemuan hukum (in concreto). ${ }^{13}$ Selain itu kajian ini juga dilengkapi dengan kajian perbandingan implementasi putusan berkaitan erat dengan perkara perdata Islam yang masuk serta kualifikasi kompetensi seorang hakim dalam proses penyelesaian perkara di Pengadilan Agama se-Provinsi Banten. Dengan begitu kajian ini menggunakan perbandingan (comparative approach).

Data primer adalah informasi yang didapat langsung dari lapangan yakni informasi-informasi lain yang didapat dari hasil wawancara penulis atau survey dari objek penelitian yang dituju. Adapun bahan hukum primer adalah yang bersifat autoritatif yang artinya mempunyai otoritas, ${ }^{14}$ yang sumbernya terdiri dari Undang-undang No.35 tahun 1999 tentang perubahan atas Undang-undang No.14 tahun 1970 tentang ketentuan-ketentuan pokok kekuasaan kehakiman, Undang-undang No.5 tahun 2004 perubahan atas Undang-undang No.14 tahun 1985 tentang Mahkamah Agung, Undang-

\footnotetext{
${ }^{9}$ Sahrwardi K. Lubis, Etika Profesi Hakim (Jakarta: Sinar Grafika, n.d.).

${ }^{10}$ John W. Creswell, Research Design, Qualitative \& Quantitative Approaches (2002: KIK Press, 2002).

${ }^{11}$ dkk Sri Mamudji, Hang Rahardjo, Metode Penelitian Dan Penulisan Hukum (Jakarta: Badan Penerbit Fakultas Hukum Universitas Indonesia, 2005).

12 Peter Mahmud Marzuki, Penelitian Hukum (Jakarta: Kencana, 2007).

${ }^{13}$ Bambang Sunggono, Metodologi Penelitian Hukum (Jakarta: PT. Rajawali Grafindo Persada, 2007), $78-79$.

${ }^{14}$ Soerjono Soekanto, Pengantar Penelitian Hukum (Jakarta: UI Press, 1982), 85.
} 
undang No.4 tahun 2004 tentang kekuasaan kehakiman, dan Kitab Undang-Undang Hukum Perdata (KUHP).

Undang-undang Perkawinan No.1 tahun 1974 tentang perkawinan, Undang-undang 7 tahun 1989 tentang Peradilan Agama, Undang-undang No.3 tahun 2006 tentang perubahan atas UU No.7 tahun 1989 tentang Peradilan Agama. Peraturan Mahkamah Agung No.1 tahun 2008 tentang Prosedur Mediasi di Pengadilan. Bahan hukum primer lainnya yang tak kalah penting adalah Al-Qur'an dan Hadits yang dapat dijadikan penguat bahwa upaya perdamaian adalah wajib dilakukan. Bahan hukum sekunder adalah bahan hukum yang menjelaskan bahan hukum primer, ${ }^{15}$ yakni berupa semua publikasi tentang hukum yang bukan merupakan dokumen-dokumen resmi. ${ }^{16}$ Publikasi tentang hukum meliputi buku-buku teks, artikel-artikel, jurnal-jurnal hukum ataupun disertasi hukum. Bahan hukum sekunder ini juga termasuk laporan buku tahunan Pengadilan Agama se-Provinsi Banten.

\section{Hasil Pembahasan}

Berdasarkan pengamatan penulis di lapangan, bahwa profesional hakim di Pengadilan agama mempengaruhi tingkat keberhasilan putusan terhadap perkara perdata Islam di Pengadilan Agama di Provinsi Banten. Dalam menjalankan tugasnya, seorang hakim memiliki kebebasan untuk membuat keputusan terlepas dari pengaruh pemerintah dan pengaruh lainnya. ${ }^{17}$ Hakim menjadi tumpuan dan harapan bagi pencari keadilan. Hakim juga memiliki kewajiban ganda, di satu pihak merupakan pejabat yang ditugasi menerapkan hukum (izhar al-hukm) terhadap perkara yang kongkrit baik terhadap hukum tertulis maupun tidak tertulis, di lain pihak sebagai penegak hukum dan keadilan dituntut untuk dapat menggali, memahami, nilai-nilai yang ada dalam masyarakat. Secara makro dituntut untuk memahami rasa hukum yang hidup di dalam masyarakat.

Sementara fungsi hakim adalah menegakkan kebenaran sesungguhnya dari apa yang dikemukakan dan dituntut oleh para pihak tanpa melebihi atau menguranginya terutama yang berkaitan dengan perkara perdata, sedangkan dalam perkara pidana mencari kebenaran sesungguhnya secara mutlak tidak terbatas pada apa yang telah dilakukan oleh terdakwa, melainkan dari itu harus diselidiki dari latar belakang perbuatan terdakwa. ${ }^{18}$ Artinya, hakim mengejar kebenaran materil secara mutlak dan tuntas. Dan tugas hakim adalah melaksanakan semua tugas yang menjadi tanggung jawabnya untuk memberikan kepastian hukum semua perkara yang masuk baik perkara tersebut telah di atur dalam Undang-undang maupun yang tidak terdapat ketentuannya. Dengan demikian, terlihat dalam menjalankan tanggung jawabnya hakim harus bersifat obyektif, karena merupakan fungsionaris yang ditunjuk undang-undang untuk memeriksa dan mengadili perkara, dengan penilaian yang

\footnotetext{
${ }^{15}$ Soerjono Soekanto, 53-54.

${ }^{16}$ Peter Mahmud Marzuki, Penelitian Hukum, 141.

17 Cik Hasan Bisri, Peradilan Islam Dalam Tatanan Masyarakat Indonesia (Bandung: Rosda Karya,

${ }^{18}$ Abdul Kadir Muhammad, Hukum Acara Perdata Indonesia (Jakarta, 2004), 34.
} 1997), 104. 
obyektif pula karena harus berdiri di atas kedua belah pihak yang berperkara dan tidak boleh memihak salah satu pihak.

Prosedur yang tampak di pengadilan menuntut hakim untuk mengikuti hukum acara yang berlaku dan peraturan perundangan yang berlaku, yang lebih menuntut lagi harus berpikir normatif. Undang-undang Nomor 4 Tahun 2004 tentang kekuasaan kehakiman tidak lagi menempatkan Undang-undang sebagai pedoman atau tafsir tunggal bagi hakim dalam memutus perkara. Hakim wajib menggali, mengikuti, dan memahami nilai-nilai hukum dan rasa keadilan yang hidup dalam masyarakat. Hakim kelihatannya memutus perkara perceraian sesuai dengan prosedur hukum acara yang berlaku, namun dalam pembuatan putusan menuntut hakim untuk mempertimbangkan beberapa konsekuensi daripada putusannya. Seorang hakim haruslah memiliki kualifikasi dan kualitas tertentu. Lebih-lebih setelah diundang-undangkannya Hukum Acara Peradilan Agama No. 7/1989. Paling kurang ada delapan persyaratan yang harus dipenuhi seorang hakim, diantaranya bertaqwa kepada Tuhan Yang Esa, berwibawa, jujur, adil dan berkelakuan tidak tercela. Di bawah ini akan dijelaskan faktor yang harus dimiliki seorang hakim anatara lain:

\section{Kecerdasan hakim}

Istilah kecerdasan padanan katanya yaitu "intelegensi". Intelegensi berasal dari bahasa latin intelligere yang berarti menghubungkan atau menyatukan satu sama lain (to organize, to relate, to bind together). ${ }^{19}$ Apabila kita telusuri asal-usulnya kata intelegensi erat sekali hubungannya dengan kata intelek. Intelektus atau intelek adalah bentuk participium perpectum (pasif) dari intellegere, sedangkan intelegensi participium praesens (aktif) dari kata yang sama. Bentuk-bentuk kata itu memberikan indikasi bahwa intelek lebih bersifat pasif sedangkan integensi lebih bersifat aktif. Berdasarkan pemahaman tersebut, dapat disimpulkan bahwa intelek adalah daya atau potensi untuk memahami, sedangkan intelegensia adalah aktivitas atau perilaku yang merupakan perwujudan dari daya atau potensi tersebut. Alex Sobur mendefinisikan intelegensia sebagai "kemampuan untuk berpikir secara abstrak". ${ }^{20}$ Terman "kemampuan untuk menyesuaikan diri dengan lingkungannya" (Colvin) "teknik untuk memperoleh informasi yang disediakan oleh indera" (Hunt) menurut riset dan temuan psikologi ditemukan tiga macam kecerdasan: rasional, emosional, dan spritual.

Kecerdasan di atas amat manarik untuk dikaitkan dengan cara berpikir dalam hukum, yang pada gilirannya akan mempengaruhi tindakan hakim dalam menjalankan hukum. ${ }^{21}$ Kecerdasan rasional menuntut hakim dalam menjalankan hukum untuk menerapkan kemampuan penalaran logis, dimana menuntut hakim untuk mengkaidahi peristiwa hukum yang terjadi dengan mendasarkan pada peraturan formal. Kecerdasan rasional dalam ilmu hukum yang terjadi dengan mendasarkan pada peraturan formal. Kecerdasan rasional dalam ilmu hukum disebut "mahkotanya hakim" untuk

\footnotetext{
${ }^{19}$ Daneil Goleman, Emotional Intelligence (New York: Bantam Dell, 1995), 54.

${ }^{20}$ Alex Sobur, Psikologi Umum, ed. Pustaka Setia (Bandung, 2003), 209.

${ }^{21}$ I Jauhari, "Penetapan Teori Tahkim Dalam Penyelesaian Sengketa Hak Anak (Hadlanah) Di Luar Pengadilan Menurut Hukum Islam," Asy-Syir'Ah 45, no. Ii (2013): 67, http://journal.uinsuka.ac.id/media/artikel/ASY124502-71-93-1-PB.pdf.
} 
menggunakan cara berpikir positivistis-dogmatis. Kecerdasan emosional, kecerdasan yang dapat digunakan oleh hakim mediator dan menjalankan hukum untuk mempertimbangkan lingkungan, habitat dengan mempertimbangkan faktor konteks yang dibarengi dengan rasa empati, komitmen dan dedikasi. Kecerdasan ini menuntut hakim untuk melakukan "perang dibalik toganya". 22

Sedangkan kecerdasan spiritual, kecerdasan dimana hakim dalam menjalankan hukum tidak dengan menerapkan huruf-huruf peraturan begitu saja, tetapi menemukan makna dan nilai yang terkandung dalam peraturan. Kecerdasan spiritual merupakan kecerdasan hakim dalam menjalankan hukum sebagai kecerdasan "refresentasi ketuhanan". Hakim menggunakan kecerdasan spritual sebagai dasar pertimbangan dalam penjatuhan putusan karena dengan kemampuan spritualnya seorang hakim dalam menjatuhkan putusan jelas tidak hanya berpacu pada undang-undang semata namun juga mampu berpacu pada rasa kemanusiaan untuk berbuat adil dengan putusannya berdasarkan nilai-nilai spritual.

Jika menggunakan kecerdasan rasional maka akan terlihat pada peraturan perundang-undangan seperti KHI, kecerdasan emosional dapat melihat dari kepentingan para pihak yang bersengketa, sedangkan kecerdasan spritual menuntut hakim untuk memberi pertimbangan terhadap para pihak. Berdasarkan pengamatan penulis dari perkara yang dilaksanakan masing-masing Pengadilan Agama di Provinsi Banten menunjukan bahwa kecerdasan hakim berpengaruh dalam proses mediasi dan para pihak saling menerima pandangan-pandangan dari hakim mediator untuk memperbaiki rumah tangga pihak-pihak yang bersengketa agar dapat rukun kembali tanpa adanya gugatan masing-masing pihak. ${ }^{23}$

Kemudian para pihakpun menilai bahwa kecerdasan mempengaruhi hakim dalam pelaksanaan mediasi yang diselenggarakan karena menuntut hakim untuk melakukan pembuktian dari berbagai pihak, yang tentunya kecerdasan itu amat perlu untuk melakukan penggalian peristiwa hukum dari para pihak beserta saksi-saksi. Hal tersebut juga dibenarkan oleh kalangan pengacara bahwa hakim tidak hanya mencari peraturan tentang kaidah yang mengatur tentang penyelesaian perkara, tetapi kecerdasan itu menuntut untuk mencari pihak yang mana kompeten, dengan demikian bukan hanya undang-undang yang perlu dipelajari oleh hakim. Sedangkan hakim pengadilan Agama mengakui bahwa kecerdasan hakim sangat penting, mengingat mediasi akan mempengaruhi terhadap dedikasi seorang hakim. Hakim sebagai penegak hukum melalui peradilan dituntut perannya sebagai penafsir yang baik terhadap perundang-undangan, isi dan jiwa sesuai dengan rasa keadilan masyarakat.

\section{Kepribadian}

Kata kepribadian berasal dari bahasa latin persona yang berarti gambaran sosial tertentu yang diterima oleh individu dari kelompok atau masyarakat, kemudian individu tersebut diharapkan

${ }^{22}$ Alport dalam Alex Sobur, Teori Kepribadian, PT. Eresco (Bandung, 1991), 209.

23 Abdul Manan, "Hukum Islam Dalam Bingkai Pluralisme Bangsa: Persoalan Masa Kini Dan Harapan Masa Depan,” Jurnal Asy-Syir'ah 42, no. 2 (2008): 78, https://doi.org/10.14421/asy-syir'ah.2008.\%x. 
bertingkah laku berdasarkan atau sesuai gambaran sosial yang diterimanya. ${ }^{24}$ Awal munculnya, pertama kali istilah kepribadian yaitu sebagaimana didefinisikan oleh Alport adalah: 1) Kepribadian itu merupakan organisasi yang dinamis, ia tidak statis, tetapi senantiasa tidak berubah setiap saat, 2) organisasi tersebut terdapat dalam diri individu. Jadi, tidak meliputi hal-hal yang berada di luar individu, 3) organisasi itu terdiri dari sistem psikis, menurut Allport meliputi sifat dan bakat, serta sistem fisik (anggota dan organ tubuh yang saling terkait), 4) organisasi itu menentukan corak penyesuaian diri yang unik dari tiap individu terhadap lingkungannya.

Menurut Schults ${ }^{25}$ mengemukakan teori kepribadian yakni psikoanalisis, interpersonal, sifat, perkembangan, humanistik, kognitif, dan behavorisme. Setiap aliran tersebut menunjukkan adanya kekuatan penting yang aktif dalam seluruh bidang kepribadian. Tipe kepribadian yang dapat diterapkan terhadap profesi hakim sebagai person dalam bidang hukum yaitu tipe kepribadian sebagaimana yang dikemukakan oleh Carl Gustav Jung yaitu: ${ }^{26}$ 1) Tipe extrovert, hakim mengeluarkan/melahirkan putusan lebih diarahkan kepada luar dirinya, kepada orang lain dan kepada masyarakat. 2) Tipe introvert, putusan yang dilahirkan oleh hakim adalah menyangkut pada kepentingan dirinya, Menurut Crow and Crow bahwa orang yang memiliki tipe extrovert mempunyai sifat berhati-hati, terbuka, lancar dalam pergaulan, ramah, penggembira, kontak dengan lingkungan besar sekali. Sedangkan tipe kepribadian introvert memiliki sifat sering diliputi rasa kekhawatiran, bersifat radikal, bersikap subjektif dan berhati-hati terhadap penderitaan tindakan yang dikeluarkan. ${ }^{27}$

Tipe kepribadian extrovert dan introvert membawa pada kepribadian hakim yang otoriter dan demokratis yang berpengaruh terhadap proses mediasi yang dilaksanakan pengadilan Agama melalui hakim mediator. Kepribadian yang otoriter dipengaruhi pada kepatuhan otoritas, paradigma konvensional yang sangat menghormati norma yang hidup dan agresi otoritarian. Sedangkan hakim dapat berkepribadian demokratis jika terilhami oleh nilai religius intrinsik (menghormati kemanusiaan melebihi kebutuhan dirinya), dan selalu melakukan pengkajian terhadap nilai religiusitas yang dianut. Hakim yang sangat memegang teguh keyakinannya untuk menyelesaikan perkara melalui mediasi berpendapat bahwa aturan dalam pengadilan menghendaki demikian, agar pihak berpikir dahulu sebelum melakukan perceraian, dan merupakan tanggung jawab hakim untuk melakukan proses mediasi di Pengadilan Agama. ${ }^{28}$

Berdasarkan keterangan Pengadilan agama di wilayah hukum Tinggi Agama Banten menunjukan bahwa hakim masih berkepribadian otoritarian dengan mengutamakan ajaran-ajaran agama yang tidak boleh mengalami perubahan sedikitpun, yang disebut oleh Altemeyer sebagai

\footnotetext{
${ }^{24}$ Alport dalam Alex Sobur, Teori Kepribadian, 10.

${ }^{25}$ Duane Schultz, Psikologi Pertumbuhan. Model-Model Kepribadian Yang Sehat (Yogyakarta: Kanisius, 1991), 56

${ }^{26}$ Carl Gustav Jung dalam M. Ngalim Purwanto, Psikologi Pendidikan (Bandung: PT. Remaja Rosda Karya, 1998), 56.

${ }^{27}$ Crow \& Crow dalam Alex Sobur, Psikologi Umum (Bandung: Pustaka Setia, 2003), 35.

${ }^{28}$ Barbara Krahe dalam Helly Prajitno Soetjipto, Perilaku Agresif (The Social Psychology of Agresion) (Yogyakarta: Pustaka Pelajar, 2005), 67-68.
} 
religius intrinsik dan fundamental. Tipe religius tersebut menurut Altemeyer mempelajari ajaran agama secara kaku dan hanya melihat apa yang tersurat dalam ajaran-ajaran agama mereka. Dalam hal ini kurang memperdulikan kepentingan si anak sehingga mementingkan diri dan kelompoknya yang menjadikan hakim otoritarian. ${ }^{29}$ Hakim cenderung memberikan pertimbangan yang lebih dalam kepada para pihak yang bersengketa agar bisa diselesaikan dengan cara mediasi bukan saling bertengkar bahkan menyalahkan yang benar dan yang salah dari pihak suami ataupun isteri.

\section{Jenis Kelamin}

Dalam pandangan psikologi, kajian tentang perbedaan jenis kelamin yaitu mencolok pada kajian aliran psikoanalisis yang menempatkan peran ibu sebagai tokoh panutan dari anaknya. Status yang melekatkan pada perempuan, cenderung perasa, lembut, sensitif dan pasif terhadap tindakan yang akan diambil. Jika dibandingkan dengan laki-laki yang cenderung keras, dan lebih aktif terhadap tindakan yang akan diambil dengan mengedepankan logika/akal pikiran. Kemampuan natural seksual perempuan yang menempatkan harus pasif dapat menjadikan lebih solid terhadap sesamanya jika dibandingkan dengan peran laki-laki.

Profesi hakim sebagai pelaksana dalam putusan pengadilan, tidak terlepas ciri yang melekat dalam dirinya sebagai hakim laki-laki/perempuan. Dalam kasus perceraian mungkin yang lebih paham adalah hakim perempuan karena didasarkan pada indera perasa perempuan yang menonjol. Sehingga perceraian merupakan peristiwa hukum yang rumit bagi hakim perempuan. Terlebih lagi ikatan batin yang kuat antara ibu dan anak jika harus dipisahkan dari ibunya, tentunya antara hakim laki-laki dan perempuan berbeda dalam melakukan komunikasi hukum dengan para pihak. Berdasarkan pengamatan penulis dan keterangan dari beberapa hakim Pengadilan Agama di wilayah hukum Pengadilan Tinggi Agama Banten mereka mengemukakan tentang pengaruh jenis kelamin dalam menetapkan keputusan proses mediasi. Berdasarkan pengalaman selama melaksanakan proses mediasi menunjukan bahwa hakim laki-laki berbeda dengan hakim perempuan dalam proses melaksanakan mediasi, dan ditegaskan kembali oleh para pihak yang melihat, mangalami dan memahami bahwa hakim perempuan lebih gampang diajak berkomunikasi karena melihat secara utuh masalah yang terjadi kepada kedua belah pihak. Akan tetapi terkadang hakim perempuan juga lebih mudah emosional terhadap suami terpancing oleh situasi pasangan karena memperlakukan istri kurang baik.

Dalam pelaksanaan mediasi hakim mediator perempuan, juga sulit terlepas dari sikap empati kepada para pihak jika terjadi perselisihan, sebagaimana dikemukakan Abdul Fattah sebagai hakim ketua "hakim juga manusia biasa, sehingga kami terkadang sulit mengendalikan emosi jika dalam pembuktiannya terdapat sikap kekerasan oleh pihak laki-laki, yang lebih membuat kami emosi adalah jika kami menangani perceraian kemudian pemohon/suami adalah dari kalangan ustad yang tentunya

${ }^{29}$ Siti Rahayu Haditono, Psikologi Perkembangan, Pengantar Dalam Berbagai Bagiannya (Yogyakarta: Gadjah Mada University Press, 2000), 114. 
tahu konsekeuensi dari pada perceraian untuk keluarganya". Berdasarkan keterangan di atas dapat disimpulkan bahwa antara hakim laki-laki dan perempuan memang dalam pelaksanaan mediasi samasama menggunakan dasar hukum yang sama, tetapi yang membedakan keduanya sikap dalam proses mediasi, yang menempatkan hakim perempuan sangat menghormati kaumnya. Dengan demikian putusan hakim perempuan berkorelasi positif dengan the woman solidarity.

\section{Usia}

Usia erat kaitannya dengan fase pertumbuhan/perkembangan yang diuraikan melalui psikologi perkembangan. Psikologi perkembangan melakukan pengkajian dan penelitian terhadap usia dengan tingkatan usia kanak-kanak, remaja, dewasa, dan usia lanjut. Perkembangan usia yang dianggap sebagai masa puncak dalam psikologi yaitu ketika usia dewasa dan penurunannya yaitu pada usia tua. Victor Hugo mengamati bahwa usia 40 tahun merupakan usia tua dari masa muda dan usia lima puluhan merupakan masa muda dari usia tua. ${ }^{30}$ Dalam usia pertengahan, bukan hanya menjadi tua dibandingkan dengan sebelumnya melainkan seorang akan menjadi bijaksana. Dapat mengetahui seluk-beluk sesuatu, dapat menemukan jalan, dapat mengenal diri sendiri, dan bertanggung jawab. Kepuasan yang lebih yaitu dapat mengetahui apa yang sedang/dapat dilakukan dan berguna pada usia puncak. Pengunaan bakat alamiah yang dibentuk oleh latihan dan diproses oleh pengalaman memberikan kepuasan dan baik untuk menunjang pekerjaan. ${ }^{31}$

Lapangan psikologi yang paling banyak disoroti dalam masa perkembangan usia yaitu intelegensia. Dengan intelegensi sebagaimana dikemukakan oleh Weschler intelegensia adalah kecakapan individu yang global dan tersusun untuk dapat bertindak terarah, berpikir yang bermakna dan bergaul dengan lingkungannya secara efisien. ${ }^{32}$ Menurut Weschler maka puncak prestasi intelegensi ada disekitar umur 20 tahun dan sesudahnya akan ada penurunan. Kemudian Weschler merevisi pendapatnya dan menganggap puncaknya pada usia 25 tahun. Juga penurunannya agak kurang dramatis daripada konsepnya yang semula. Schae menetapkan puncaknya pada usia 30 tahun, ${ }^{33}$ sedangkan Blash dan Zubek dapat menunjukan bahwa pada sementara orang puncaknya dicapai pada usia 20 tahun. ${ }^{34}$ Juga penelitian di Belanda yang dilakukan oleh Verharge (1964) mencoba untuk menunjukan bahwa mulai 20 tahun ada garis penurunan mengenai prestasi intelegensi. ${ }^{35}$ Schale menyelidiki apa hal itu betul dan bagaimana begitu, berlaku, bagi lapangan yang

\footnotetext{
${ }^{30}$ Victor Hugo dalam Brice Pit, Krisis Manusia Dewasa Dan Setengah Baya (Making the Most of Midle Age) (Jakarta: Arcan, 1986), 45.

${ }^{31}$ Jhon Clauses dalam Wibur Bradburry, Perilaku Manusia Masa Dewasa Diterjemahkan Oleh Rusmini Makmur (Jakarta: Tira Pustaka, 1987), 125.

32 Wecshler dalam F.J. Monk dan Hadinoto, Psikologi Perkembangan Pengantar Dalam Berbagai Bagiannya (Yogyakarta: Gaja Mada university Press, 1994), 67.

${ }^{33}$ Dana Zohar dalam Rahmani Astuti, Spritual Intelligence (Memanfaatkan Kecerdasan Spritual Dalam Berpikir Integralistik Dan Holistik Untuk Memaknai Kehidupan) (Bandung: Mizan, 2000), 33.

${ }^{34}$ Abu Ahmadi, Psikologi Perkembangan (Jakarta: PT Asdi Mahasatya, 2005), 67.

${ }^{35}$ F.J Monk, dkk, Psikologi Perkembangan, Pengantar Dalam Berbagai Bagiannya, (Yogyakarta: Gaja Mada university Press, 1984), 275.
} 
mana. Ia membedakan antara intelegensi yang mengalir dan intelegensi yang dikristalkan. Dengan intelegensi yang mengalir dimaksudkan kecakapan untuk dapat berubah dengan luwes, lincah, mudah mengkombinasi dan mudah dapat mengadakan orientasi dalam situasi baru. Intelegensi yang dikristalkan adalah intelegensi yang berhubungan dengan pengetahuan umum, dengan kekayaan bahasa dan pengertian bahasa. Intelegensi yang mengalir akan menunjukan penurunan sesudah mencapai puncak kedewasaan muda yaitu sekitar umur 30 tahun, tetapi intelegensi yang dikristalkan akan relatif stabil.

Bila dimensi perkembangan usia tersebut diterapkan dalam profesi hakim maka akan terlihat kemampuan hakim melakukan penalaran, pembuktian, dan pembuatan putusan pengadilan. Usia hakim yang lebih tua dapat menjadikan sebagai senioritas yang dihormati oleh hakim-hakim lainnya. Sehingga putusan akan menjadi patokan bagi hakim anggota, jika suatu saat akan menjadi hakim ketua. Kematangan usia berpengaruh terhadap perbedaan penalaran hakim. Dalam kasus hukum pidana, Hood mengatakan hakim tua memberikan pemidanaan lebih berat dan cenderung diskriminatif terhadap ras hitam. Berbeda halnya dengan perkara perdata oleh hakim yang tidak berpengaruh oleh hasil penyidikan dan penuntutan jaksa, melainkan pembuktian didominasi oleh hakim untuk dijadikan dasar/alasan hukum untuk menetapkan putusan. Kecerdasan dan pengalaman hakim yang berbeda dengan alat ukur usianya akan berbeda dalam melakukan pembuktian perkara. ${ }^{36}$

Berdasarkan keterangan di atas mengindikasikan bahwa antara hakim yang berusia muda dan berusia tua memiliki pengaruh dalam persidangan. Hakim yang berusia muda melakukan secara lues, terbuka, dan ingin mengetahui posita/peristiwa perkara secara jelas, hakim berusia tua berpikir otomatis karena melihat perkara pada akhirnya akan sama putusan dengan perkara yang sudah pernah diputus.Ternyata usia yang sebaiknya ia menjadikan berpengalaman tidak memiliki pengaruh yang besar, untuk memberikan pembuktian yang bijak dan dapat diladeni oleh hakim yang masih muda. Dengan demikian hakim yang berusia tua, senioritasnya menunjukan sebagai mesin Undang-undang. Satjipto Rahadjo memandang keadaan demikian hakim terjebak pada hukum modern yang dirancang secara formal-rasional, makna Undang-undang tidak perlu dicari lebih jauh. Ibaratnya cukup pencet tombol, putusan sudah dibuat dengan benar, hakim tidak perlu pusing berusaha menemukan makna, nilai dan moral dibelakang perkara yang akan diputus. ${ }^{37}$

Lebih jauh, dijelaskan bahwa hakim pada semua tingkatan menduduki posisi sentral dalam proses peradilan. Dalam posisi sentral itulah hakim diharapkan dapat menegakan hukum. Hanya hakim yang baik yang bisa diharapkan menghasilkan putusan yang mencerminkan rasa keadilan dan sesuai dengan hukum yang berlaku. Ada banyak kriteria hakim yang baik, antara lain memiliki kemampuan hukum (legal skill), pengalaman yang memadai, integritas, kesehatan yang baik, serta mampu mencerminkan keterwakilan masyarakat. Hal-hal lain yang harus dimiliki hakim yang cakap

\footnotetext{
${ }^{36}$ F.J Monk, dkk, 276.

${ }^{37}$ Satjipto Rahadjo, Hukum Dan Perubahan Sosial (Bandung: Alumni, 1979), 119.
} 
adalah nalar hukum ${ }^{38}$ yang baik, visi yang luas, kemampuan berbahasa dan menulis, kemampuan menegakkan hukum negara dan bertindak independen dan imparsial, di samping kemampuan administratif. ${ }^{39}$

\section{Pengalaman}

Pengalaman kerja adalah masa kerja hakim dalam menjalankan tugas peradilan. Pengalaman kerja menjadi penting karena dengan melalui pengalaman dapat diperoleh berbagai pengetahuan dan wawasan. Pengalaman kerja juga menjadikan hakim lebih luwes dan merasa gampang/terbiasa dengan jenis perkara yang akan dihadapi. Dengan pengalaman tersebut hakim dapat menjatuhkan putusan yang adil bagi para pihak yang bersengketa. Pengalaman seorang hakim di Pengadilan Agama di Provinsi Banten memiliki pengaruh yang besar dalam proses penyelesaian perkara terhadap para pihak. Pasal Pasal 28 Undang-undang Nomor 4 Tahun 2004 tentang kekuasaan kehakiman, ditegaskan hakim wajib menggali, mengikuti, dan memahami nilai-nilai hukum dan rasa keadilan yang hidup dalam masyarakat. Akan tetapi berdasarkan hasil penelitian dilapangan hakim pada kenyataannya masih menjadikan Undang-undang sebagai sumber hukum tunggal, karena curiga dan takut jika putusannya dibatalkan, akan merusak kinerja dan dedikasinya.

Pengalaman seorang hakim yang berkorelasi positif (berpengaruh) dalam proses mediasi, tampaknya menjadikan hakim sulit untuk menggali ilmu hukum dari pengalaman empiris dan menjadi model yang dapat dicontoh masyarakat. Padahal pekerjaan hakim dilingkungan pengadilan agama tidak hanya melakukan pekerjaan rutin memutus perkara tetapi juga senantiasa melakukan refleksi teoritis dan abstraksi empiris secara terus menerus sehingga dapat melahirkan ijtihad yang inovatif dalam pembangunan hukum nasional. Pengalaman hakim pada saat menemukan hukum dalam praktik di pengadilan memberi dukungan bagi konsepsi pragmatis dan teoritisnya ${ }^{40}$ Konsistensi hakim dalam menjalankan aturan tidak hanya dapat dilihat pada ruang pengadilan, tetapi juga pada tutur kata, sikap, pergaulan dan tingkah lakunya. ${ }^{41}$ Ada berbagai faktor yang mempengaruhi proses pembentukan sikap seorang. Pertama, adanya akumulasi pengalaman dari tanggapan tipe yang sama. Seotang mungkin berinteraksi dengan berbagai pihak yang mempunyai sikap yang sama terhadap suatu hal. Kedua, pengamatan terhadap sikap lain yang berbeda. Seorang dapat menentukan sikap pro atau anti terhadap gejala tertentu. Ketiga, pengalaman buruk atau baik yang pernah dialami. Keempat, hasil peniruan terhadap sikap pihak lain. Seberapa banyak hakim berpraktik dan belajar dari kesalahan serta

\footnotetext{
${ }^{38}$ Neil MacCormick, Legal Reasoning and Legal Theory (Oxford: Oxford University Press, Oxford Uni (Oxford, 1994), xi.

39 Mustafa Abdullah, Pengembangan Integritas Dan Pfofesionalisme Hakim, Makalah Pada Diskusi Panel Yang Diselenggarakan Oleh BPHN Dan Universitas Gadjah Mada (Yogyakarta, 2007).

${ }^{40}$ Gregory Leyh, Legal Hermaneutics (History, Theory, and Practice) (Berkley Los Angeles Oxford: University Of California, 1992), 107.

${ }^{41}$ Imanuel Kant dalam Wulfgaf Friedman, Teori Dan Filsafat Hukum (Legal Theory), 1990, 104.
} 
mengacu pada hakim senior, merupakan pengalaman yang diperoleh yang akan berpengaruh terhadap berbagai kasus yang dihadapinya. ${ }^{42}$

Seperti dalam perkara perceraian pihak yang mengajukan gugatan harus mampu memberikan dan menunjukan bukti-bukti atas gugatannya, maka dengan pengalaman gugatan yang cukup seorang hakim tidak akan mudah menerima bukti-bukti, tentu harus dapat memahami mana bukti yang terkait dan mana bukti yang tidak terkait dengan gugatan perceraian yang ajukan kepadanya. Pengalaman hakim dijelaskan ketua pengadilan Tinggi Agama Banten "bahwa dalam kepangkatan hakim itu ada yang namanya DUS (daftar urutan senioritas hakim) itu biasanya dipakai untuk susunan majelis, bagi hakim yang senior tinggi Ia duduk dikursi hakim ketua, dan hakim yang di bawahnya duduk di sebelah kanan kemudian senioritasnya lebih rendah Ia duduk di sebelah kiri (sesuai aturan Mahkamah Agung), untuk hakim di Pengadilan Agama di Provinsi Banten rata-rata mereka menjadi hakim sudah 15 tahun, dan ada yang 20 tahun. Dalam hakim di sebut DUS dan dalam kepegawaian ada DUK (Daftar Urutan Kepegawaian) jadi mereka lebih tinggi menjadi hakimnya maka ia-lah yang dianggap senior. Akan tetapi untuk hakim di luar jawa rata-rata mereka lebih muda-muda dibandingkan dengan hakim yang ada di pulau jawa”.

Melihat dari penjelasan tersebut di atas, jelas bahwa hakim di Pengadilan Agama di Provinsi Banten memiliki tingkat pengalaman yang cukup tinggi dengan skala antara 15 (lima belas) tahun menjadi hakim, sehingga jelas bahwa masing-masing hakim Pengadilan Agama di wilayah hukum Pengadilan Tinggi Agama Banten dalam menjatuhkan putusan hukum berdasarkan pengalaman yang cukup tinggi.

\section{Frekuensi perkara}

Selain faktor psikologis, berdasarkan penelitian dilapangan yang dilakukan Pengadilan Agama di Provinsi Banten, ada faktor eksternal yang berpengaruh terhadap aspek psikologis hakim sehingga seorang hakim tidak serius dan consent menangani perkara. Perkara yang terlalu banyak (frekuensi perkara) akan menjadikan hakim sebagai mesin undang-undang, tanpa memberikan ruang gerak untuk berkreasi, mengekspresikan metode penemuan hukum melalui penalaran logika deduktif maupun induktif. Hakim akan ngotot dan terburu-buru menyelesaikan perkara, apalagi dengan adanya tuntutan dari atasannya untuk mempercepat selesai berkas perkaranya. Kondisi demikian membawa hakim dalam pusaran lebih mengedepankan selesainya perkara dari pada menghindari kesalahan penalaran, pertimbangan dan penemuan hukum.

Pengadilan Agama di Provinsi Banten, sidang rata-rata dimulai oleh hakim, jam 09.00 pagi dan berakhir jam 03.00 sore. Waktu tersebut dipergunakan oleh hakim untuk mengadili perkara terdiri atas 10 sampai dengan 25 perkara. Dalam persidangan tersebut hakim tidak hanya akan berhadapan dengan masalah perceraian, tetapi juga akan berhadapan dengan perkara lainnya seperti sengketa

\footnotetext{
${ }^{42}$ Imanuel Kant dalam Wulfgaf Friedman, 93.
} 
warisan dan sengketa harta bersama yang menuntut hakim bekerja keras untuk melakukan komunikasi hukum dengan para pihak. Keluhan dari hakim pengadilan memiliki pendapat yang sama bahwa perkara yang harus di adili dalam tiap hari yang sangat banyak rasanya membuat kami kelelahan dan harus kerja keras tiap masa dan waktu sidang, belum lagi perilaku para pihak yang sangat beragam dalam persidangan, membuat kami sulit mengontrol emosi. Frekuensi perkara yang terlalu banyak harus diadili oleh hakim akan mempengaruhi aspek kognitif dan emosi hakim. Hakim akan menjadi lupa bahwa putusannya sudah jauh dari harapan keadilan, karena cenderung perkara akan diusahakan tidak jauh berbeda dengan putusan yang sebelumnya, tanpa sadar bahwa telah dipengaruhi oleh kondisi internalnya seperti kepribadian yang otoriter untuk melahirkan putusan.

\section{Kesimpulan}

Profesionalisme Hakim dalam melaksanakan fungsi dan kewenangan di pengadilan agama di Provinsi Banten upaya menegakkan hukum yang berkeadilan, melalui putusannya diharapkan mampu menerapkan hukum yang benar dan adil, dapat memberi pendidikan dan pelajaran kepada yang berperkara di pengadilan, memberikan koreksi dengan tegas, memberikan prepensi serta memberi represip dengan tegas, dapat merekayasa tatanan masyarakat pada masa yang akan datang, serta harus mampu juga berperan mendamaikan pihak yang berperkara, yang dalam melakukan peran-peran tersebut tetap berpegang teguh pada Kode Etik dan Pedoman Perilaku Hakim.

Hakim pengadilan agama di Provinsi Banten sebagai penegak hukum senantiasa harus memperhatikan dan mengikuti dinamika masyarakat, sebab dalam kenyataannya hukum yang tertuang dalam peraturan perundang-undangan sering tidak mampu menjangkau kebutuhan yang ada. Oleh karena itu hakim dituntut mampu menguasai sistem hukum dalam penerapannya terhadap persoalanpersoalan yang timbul dalam masyarakat (law in action). Setiap putusan hakim harus berorientasi kepada rasa keadilan masyarakat sehingga masyarakat akan merasa terpelihara dan terlindungi kepentingannya, dan pada gilirannya lembaga peradilan mendapat simpati masyarakat serta diletakkan dalam kedudukan yang sangat terhormat. Apabila kondisi demikian ini dapat terwujud, maka masyarakat dengan sendirinya akan menyadari bahwa hukum lahir untuk mengatur. Peranan Hakim bukan semata-mata sebagai corong undang-undang yang memutus perkara hanya mendasarkan kepada pertimbangan tekstual sebuah peraturan, melainkan harus mengutamakan rasa keadilan mastarakat. Putusan hakim harus didasarkan kepada suatu keyakinan yang jernih berdasarkan suara hati nurani. Oleh karena itu dalam pertimbangannya senantiasa harus memperhatikan aspek filosofis maupun sosiologis agar putusannya menyentuh rasa keadilan masyarakat. Wallau a'lam bisshowaab 


\section{Daftar Pustaka}

Abdul Kadir, Muhammad. Hukum Acara Perdata Indonesia. Jakarta, 2004.

manan, Abdul, 'Peranan Peradilan Agama Dalam Perspektif Pembaharuan Hukum Islam: Studi Kasus

Terhadap Putusan-Putusan Di Lingkungan Peradilan Agama DKI Jakarta', Disertasi,” 2004.

Ahmadi, Abu, Psikologi Perkembangan. Jakarta: PT Asdi Mahasatya, 2005.

Ali, Achmad, Menguak Tabir Hukum: Suatu Kajian Filosofis Dan Sosiologis, 2014.

Sobur, Alex, Psikologi Umum. Edited by Pustaka Setia. Bandung, 2003.

Alport dalam Alex Sobur. Teori Kepribadian. PT. Eresco. Bandung, 1991.

Arifin, Jaenal. 'Reformasi Hukum Di Indonesia Dan Implikasinya Terhadap Peradilan Agama:

Analisis Terhadap Eksistensi Peradilan Agama Di Era Reformasi 1998-2008)’, Disertasi,” 2008.

Sunggono, Bambang, Metodologi Penelitian Hukum. Jakarta: PT. Rajawali Grafindo Persada, 2007.

Krahe, Barbara, dalam Helly Prajitno Soetjipto. Perilaku Agresif (The Social Psychology of Agresion). Yogyakarta: Pustaka Pelajar, 2005.

Gustav Jung, Carl, dalam M. Ngalim Purwanto. Psikologi Pendidikan. Bandung: PT. Remaja Rosda Karya, 1998.

Hasan Bisri, Cik, Peradilan Islam Dalam Tatanan Masyarakat Indonesia. Bandung: Rosda Karya, 1997.

Crow \& Crow dalam Alex Sobur. Psikologi Umum. Bandung: Pustaka Setia, 2003.

Zohar, Dana, dalam Rahmani Astuti. Spritual Intelligence (Memanfaatkan Kecerdasan Spritual Dalam Berpikir Integralistik Dan Holistik Untuk Memaknai Kehidupan). Bandung: Mizan, 2000.

Goleman, Daneil, Emotional Intelligence. New York: Bantam Dell, 1995.

Schultz, Duane, Psikologi Pertumbuhan. Model-Model Kepribadian Yang Sehat. Yogyakarta: Kanisius, 1991.

Effendi, Satria. Hukum Keluarga Modern., n.d.

F.J Monk, dkk. Psikologi Perkembangan, Pengantar Dalam Berbagai Bagiannya,. Yogyakarta: Gaja Mada university Press, 1984.

Leyh, Gregory, Legal Hermaneutics (History, Theory, and Practice). Berkley Los Angeles Oxford: University Of California, 1992.

Kant, Imanuel, dalam Wulfgaf Friedman. Teori Dan Filsafat Hukum (Legal Theory), 1990.

Jauhari, I. "Penetapan Teori Tahkim Dalam Penyelesaian Sengketa Hak Anak (Hadlanah) Di Luar Pengadilan Menurut Hukum Islam.” Asy-Syir'Ah 45, no. Ii (2013). http://journal.uinsuka.ac.id/media/artikel/ASY124502-71-93-1-PB.pdf.

Clauses, Jhon, dalam Wibur Bradburry. Perilaku Manusia Masa Dewasa Diterjemahkan Oleh Rusmini Makmur. Jakarta: Tira Pustaka, 1987.

Creswell, John W., Research Design, Qualitative \& Quantitative Approaches. 2002: KIK Press, 2002.

Manan, Abdul. "Hukum Islam Dalam Bingkai Pluralisme Bangsa: Persoalan Masa Kini Dan Harapan Masa Depan." Jurnal Asy-Syir'ah 42, no. 2 (2008). https://doi.org/10.14421/asysyir'ah.2008.\%x.

Mu'allim, Amir bin, "No Title'Yurisprudensi Peradilan Agama: Studi Pemikiran Hukum Islam Dilingkungan Pengadilan Agama Se-Jawa Tengah Dan Pengadilan Tinggi Agama Semarang, 1991-1997', Disertasi," 2003.

Abdullah, Mustafa, Pengembangan Integritas Dan Pfofesionalisme Hakim, Makalah Pada Diskusi Panel Yang Diselenggarakan Oleh BPHN Dan Universitas Gadjah Mada. Yogyakarta, 2007.

Cormick, Neil Mac, Legal Reasoning and Legal Theory (Oxford: Oxford University Press. Oxford Uni. Oxford, 1994.

Lubis, Nur Ahmad Fadhil, "No Title'Islamic Justice in Transition: A Socio-Legal Study of Agama Court Judges in Indonesia'," 1994.

Marzuki, Peter Mahmud, Penelitian Hukum. Jakarta: Kencana, 2007.

Ritonga. "No Title“Hak-Hak Wanita Dalam Hukum Keluarga Islam Di Indonesia Implementasinya Dalam Putusan-Putusan Peradilan Agama DKI JakartaTahun 1990-1995,, 2003.

Lubis, Sahrwardi K., Etika Profesi Hakim. Jakarta: Sinar Grafika, n.d.

Rahadjo, Satjipto, Hukum Dan Perubahan Sosial. Bandung: Alumni, 1979.

Haditono, Siti Rahayu, Psikologi Perkembangan, Pengantar Dalam Berbagai Bagiannya. 
Yogyakarta: Gadjah Mada University Press, 2000.

Soekanto, Soerjono, Pengantar Penelitian Hukum. Jakarta: UI Press, 1982.

Mamudji, Sri, Hang Rahardjo, dkk. Metode Penelitian Dan Penulisan Hukum. Jakarta: Badan Penerbit Fakultas Hukum Universitas Indonesia, 2005.

Undang-Undang Nomor 4 Tahun 2004 Tentang Kekuasaan Kehakiman Pasal 28 Ayat 1, n.d.

Hugo, Victor, dalam Brice Pit. Krisis Manusia Dewasa Dan Setengah Baya (Making the Most of Midle Age). Jakarta: Arcan, 1986.

Wecshler dalam F.J. Monk dan Hadinoto. Psikologi Perkembangan Pengantar Dalam Berbagai Bagiannya. Yogyakarta: Gaja Mada university Press, 1994. 